
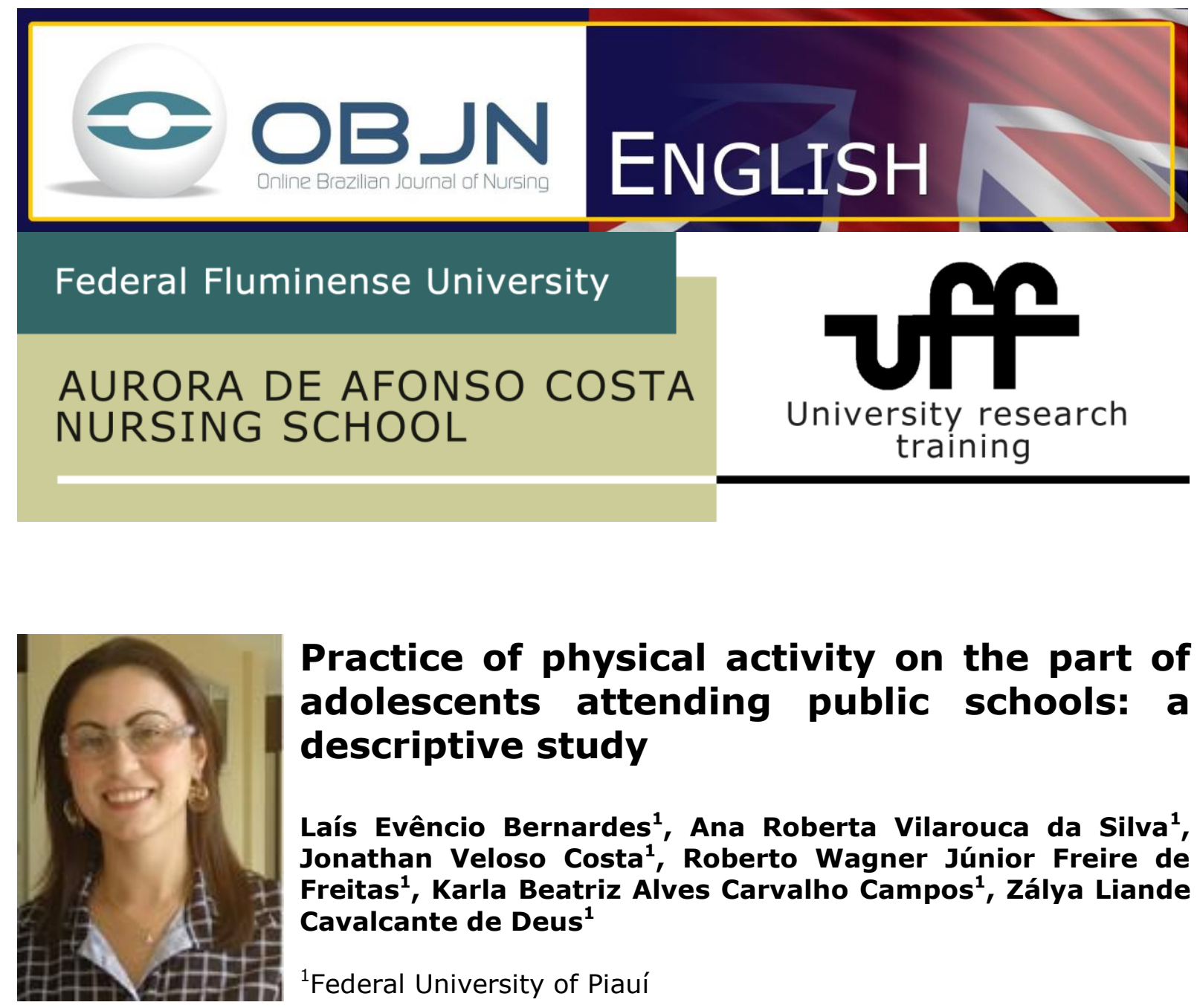

\title{
Practice of physical activity on the part of adolescents attending public schools: a descriptive study
}

\author{
Laís Evêncio Bernardes ${ }^{1}$, Ana Roberta Vilarouca da Silva ${ }^{1}$, \\ Jonathan Veloso Costa ${ }^{1}$, Roberto Wagner Júnior Freire de \\ Freitas ${ }^{1}$, Karla Beatriz Alves Carvalho Campos ${ }^{1}$, Zálya Liande \\ Cavalcante de Deus ${ }^{1}$
}

${ }^{1}$ Federal University of Piauí

\begin{abstract}
Objective: To determine the practice of physical activity on the part of adolescents from public schools in the city of Picos, Piauí. Methods: A descriptive study involving a sample of 145 adolescents of both genders aged 12 to 18 years. Data collection occurred from August to December 2010, using a specifically designed form. Results: Among the participants, $62.8 \%$ were female with average age of 14.8 years ( \pm 3.19 ). It was observed that $49.7 \%$ of the participants were classified as physically inactive. Of these, $86.1 \%$ were female $(p=0.000), 58.3 \%$ were aged between 12 and 14 years, $8.3 \%$ had a high body mass index, $9.7 \%$ had altered glucose and $45.8 \%$ had high blood pressure. Discussion: Female and younger adolescents are more sedentary. This result is similar to the results of other studies on the same subject. Conclusion: The regular practice of physical activity offers many health benefits and can contribute to the prevention of chronic non-communicable diseases.
\end{abstract}

Keywords: Motor activity, Lifestyle, Adolescent Health 


\section{INTRODUCTION}

In recent decades a transition in terms of the epidemiological profile of individuals has been occurring, especially in developing countries, moving from the predominance of infectious diseases to a greater prevalence of Chronic Non-communicable Diseases (NCDs). These are known for having a prolonged natural history with multiple complex risk factors. In this context, we may highlight diabetes mellitus type 2, obesity and cardiovascular diseases $^{(1)}$. In Brazil, the NCDs and external causes were the leading cause of death in 2009 , accounting for $85 \%$ of total deaths ${ }^{(2)}$.

In 2006, the presentation of the first edition of the study Surveillance of Risk Factors and Protection of Chronic Diseases through Telephone Interviews (VIGITEL), showed that $11.4 \%$ of Brazilians were obese. By 2007 , this figure had risen to $12.9 \%{ }^{(3)}$.

The main risk factors associated with these diseases are related to the parameters connected to lifestyle. Among them, the lack of physical inactivity is gaining prominence as one of the factors associated with the development of several chronic diseases, constituting a major problem in terms of public health.

It is now known that physical inactivity, combined with a greater time spent on lowintensity activities such as passive practices that require minimal physical effort, such as watching television, using computers for a long time, playing video games and others, contribute significantly to weight gain in adolescents.

Several studies have been conducted to investigate the relationship between the risk of NCDs and physical activity. The evidence confirms an inverse relationship between the variables. Moreover, the high prevalence of physical inactivity in adolescence increases the likelihood of sedentary adults ${ }^{(4,5)}$.

The regular practice of physical activity offers many health benefits and may work as a means of prevention, control, treatment or rehabilitation of chronic disorders such as type 2 diabetes.

The benefits of a physically active life in childhood and adolescence are important for the biological process of human growth and development, as it helps to control body weight and blood glucose concentration, and improves musculoskeletal functions. Physical activity also has psychological effects as it improves self-esteem, reduces depression, and enables better social interaction. 
The study of physical activity in adolescence and related factors becomes relevant to health promotion. Therefore, with the spread of such practices, it is possible to avoid the appearance of several NCCDs, whose management is costly and often painful for the individual and his family. Based on the foregoing, the present work aims to understand the physical activities of adolescents from public schools in the city of Picos, located in the state of Piauí (PI).

\section{METHOD}

This is a descriptive study that is part of a research project entitled "Preventive actions in the control of Diabetes Mellitus Type 2". This also has another sub-project entitled: "Investigation of the risk factors for Type 2 Diabetes Mellitus in adolescents." The project is conducted in two public schools in the city of Picos, Piauí, with support from the National Council for Scientific and Technological Development - CNPq. The studied population is comprised of 145 adolescents aged 12 to 18 years, of both genders, regularly enrolled in those schools.

The subjects were randomly selected by lot from those who agreed to participate in the study and who presented the term of consent properly signed by them and their parents or guardians. We excluded students diagnosed with chronic diseases which impacted directly on their weight and height, and those who, at the time of assessment, presented some difficulty in terms of obtaining anthropometric measures.

Data collection was conducted from August to December 2010. As a data collection instrument we used a form with the following variables: age, gender, income, education, weight, height, BMI, average blood pressure classification after three measurements and capillary blood glucose measurements at random.

Data analysis was made using SPSS software version 17.0, through which were calculated the averages and standard deviations of the variables. To determine associations between variables, we used the $\chi 2$ test. We considered as being statistically significant analyzes with $\mathrm{p}<0.05$.

The study was conducted after the approval of the Ethics Committee in Research of the Federal University of Piauí, according to protocol CAAE 0078.0.045.000-10. We met the requirements of the Guidelines and Standards of Research in Humans in terms of ethical 
issues of research involving human beings, presented in Resolution 196/96 of the National Health Council (NHC).

\section{RESULTS}

We evaluated 145 adolescents of both genders, of which $62.7 \%$ were female. Participants were aged between 12 and 18 years, with an average of 14.8 years. Regarding the family income of these adolescents, the results showed that, in most cases, they live in families receiving up to two minimum wages $(84.1 \%)$. As for the classification of students in terms of teaching modality, approximately $75.2 \%$ of the students attended elementary school.

With regard to the practice of physical activity, we found that $49.7 \%$ were classified as physically inactive. It is also noteworthy that among the inactive ones, $86.1 \%$ were female $(p=0.000), 58.3 \%$ were aged between 12 and 14 years, $8.3 \%$ had elevated BMI, 9.7\% presented questionable glycemia, and $45.8 \%$ had high blood pressure.

Table 1. Distribution of the sample, according to the association of physical activity with socioeconomic and clinical variables. Picos, Piaui, Brazil, 2010

\begin{tabular}{|c|c|c|c|c|c|}
\hline \multirow{3}{*}{ Variables } & \multicolumn{4}{|c|}{ Practice of Phisical Activity } & \multirow[b]{2}{*}{$p$} \\
\hline & \multicolumn{2}{|c|}{ YES } & \multicolumn{2}{|c|}{ No } & \\
\hline & $N$ & $\%$ & $n$ & $\%$ & \\
\hline Gender & & & & & 0,000 \\
\hline Female & 29 & 39,7 & 62 & 86,1 & \\
\hline Male & 44 & 60,3 & 10 & 13,9 & \\
\hline Age & & & & & 0,454 \\
\hline $12-14$ & 47 & 64,4 & 42 & 58,3 & \\
\hline $15-18$ & 26 & 35,6 & 30 & 41,7 & \\
\hline BMI & & & & & 0,791 \\
\hline Normal & 66 & 90,4 & 66 & 91,7 & \\
\hline High & 7 & 9,6 & 6 & 8,3 & \\
\hline Glycemia & & & & & \\
\hline Normal & 65 & 89 & 65 & 90,3 & 0,807 \\
\hline Dubious & 8 & 11 & 7 & 9,7 & \\
\hline Blood pressure & & & & & 0,115 \\
\hline Normal & 30 & 41,1 & 39 & 54,2 & \\
\hline High & 43 & 58,9 & 33 & 45,8 & \\
\hline
\end{tabular}

(1) $x^{2}$ test 
Of the adolescents who reported practicing some kind of activity, the most common exercise was football (54.8\%), both among men (34.2\%) and among women (20.6\%).

Table 2. Physical activities practiced by active adolescents according to gender. Picos, Piaui, Brazil, 2010.

\begin{tabular}{lcccccc}
\hline $\begin{array}{l}\text { Phisical } \\
\text { Activity }\end{array}$ & Male & \multicolumn{3}{c}{ Female } & \multicolumn{3}{c}{ TOTAL } \\
\hline Bicycle & $n$ & $\%$ & $n$ & $\%$ & $n$ & $\%$ \\
Soccer & 6 & 8,2 & 2 & 2,7 & 8 & 10,9 \\
Hiking & 25 & 34,2 & 15 & 20,6 & 40 & 54,8 \\
Bodybuilding & 1 & 1,4 & 8 & 11 & 9 & 12,4 \\
Swimming & 6 & 8,2 & 2 & 2,7 & 8 & 10,9 \\
Others & 1 & 1,4 & - & - & 1 & 1,4 \\
\hline TOTAL & 5 & 6,9 & 2 & 2,7 & 7 & 9,6 \\
\hline
\end{tabular}

\section{DISCUSSION}

Taking as a reference for classifying as sedentary, adolescents who practiced physical exercises for less than thirty minutes and less frequently than three times a week ${ }^{(6)}$, the study found that $49.7 \%$ of the youngsters studied do not engage in physical activity. Other studies have found higher percentages of physical inactivity among adolescents, namely, $67.8 \%^{(7)}$ and $64.3 \%{ }^{(8)}$.

With regard to the level of physical activity between genders, it was found that $18.5 \%$ of boys were inactive, while among girls the percentage was much higher at $68.1 \%$. It is known from many publications that women are less active than men ${ }^{(9.10)}$.

Since early ages it is accepted the idea that men and women have different roles in sociecy, being the men traditionally characterized by the tasks related to work and manual labor, while women are seen connected to family and domestic chores ${ }^{(12)}$. This difference in the levels of physical activity can be even higher when the instruments used to evaluate the physical activity do not contemplate occupational activities, domestic chores, transportation or family tasks. However, even when objective methods to evaluate physical activity are used, the boys are more physically active than the girls ${ }^{(13)}$. 
A study about the barriers in the practices of physical activity among teenagers of both genders pointed that only "not having someone to take me" did not have any difference between the sexes. "Not having the company of friends" and "Being lazy" were the most mention barriers, by the boys (30.4\%) and girls ( $51.8 \%)$; however the barrier strongly associated to the highest levels of insufficient physical activity was "Preferring other activities", by the boys (OR $=5.02(2.69-9.37) ; \mathrm{p}<0.05)$ and girls $(\mathrm{OR}=7.10(3.71-$ $13.60) ; \mathrm{p}<0.05)^{(14)}$.

Besides these evidences, there is scarce information about the most mentioned among Brazilian youngsters. Until the present moment, only one study was found regarding this topic in Brazilian literature ${ }^{(15)}$. In fact, the majority of the evidences available regarding the prevalence of barriers to physical activity in the Brazilian population are originated in studies performed with adults ${ }^{(16,17)}$.

One important results, from a study performed in the Brazilian state of Pernambuco also identified that women were less active, and that the participation in Physical Education classes during their Middle and High School years is an associated factor for both the current level of physical activity and the habit of watching TV for three or more hours a day (a sedentary behavior trace).

Besides this factor, the results indicate that the place of residency, the work shift, the occupational status and gender discriminate significantly the general health habits ${ }^{(18)}$.

In a research performed in the city of Maceió, with 1,253 students, it was seen a prevalence in sedentary lifestyle in $93.5 \%$ of them, most frequent in female teenagers; there was no association between the level of physical activity and the overweight or excessive body fat; soccer and dance were, respectively, the most frequent activities among boys and girls; $60 \%$ of the students do not have any Physical Education class ${ }^{(19)}$. In a study in the Brazilian state of Ceará, with 307 students, has found that more than a half of them, $207(67.4 \%)$, were classified as physically inactive. It also highlights that the percentage of active boys (71\%) was 2.45 times higher than the percentage of active girls $(29 \%)(p=0.000)$ and; that around $20 \%$ of the teenagers were overweight. Besides that, the cases of overweight were higher among inactive youngsters, as the percentages Bernardes LE, Silva ARV, Costa JV, Freitas RWJF, Karla Beatriz Alves Carvalho Campos KBAC, Deus ZLC.. Practice of physical activity on the part of adolescents attending public schools: a descriptive study. Online braz $\mathrm{j}$ nurs [Internet]. $2013 \mathrm{Apr}$ [cited year mouth day]; 12 (1): 209-17. Available from: http://www.objnursing.uff.br/index.php/nursing/article/view/3632 
of overweight $(81 \%)$ and obesity $(18 \%)(p=0.001)$ demonstrate. In arterial pressure, it was identified that $8.7 \%$ of the overweight teens and $11.7 \%$ of the obese ones were in a limit blood pressure and elevated blood pressure, respectively ${ }^{(7)}$.

In schools of the city of Teresina, 383 students (190 boys and 193 girls) were evaluated. Among the boys, $21.5 \%$ had a sedentary lifestyle; $24.2 \%$ were insufficiently active;

$2.6 \%$ were obese and; $8.4 \%$ were overweight. Among the girls, $32.1 \%$ had a sedentary lifestyle; $9.3 \%$ were insufficiently active; $1.5 \%$ were obese and; $13.9 \%$ were overweight $^{(20)}$.

Thus, it is observed that the physical inactivity can interfere in weight and the pressure levels of the students, predisposing them chronic diseases, which, in the past, were only seen in adults.

\section{CONCLUSION}

In the population analyzed, it could be seen that almost half did not practice physical activity. A limitation with regard to this work, and one which has also been reported by other authors, is the lack of a unified instrument for the classification of active and nonactive adolescents.

The importance of the school in shaping adolescents' healthy habits is apparent. The school, along with parents, teachers and the leaders of relevant bodies should promote activities that develop students' interest in physical activity, as well as the nurses, as the school is a fertile field for actions of health promotion, which is described in both Strategy in Family Health and the Health in School Program.

It is noteworthy that one of the schools participating in this study was part of the More Education Program, created by the Federal Government in 2007. It aims to increase the educational provision in public schools through optional activities. These were grouped into a number of macro-fields, namely: pedagogical monitoring, environment, sport and leisure, human rights, culture and arts, digital culture, prevention and health promotion, educational communication, scientific education and economic education. A great Bernardes LE, Silva ARV, Costa JV, Freitas RWJF, Karla Beatriz Alves Carvalho Campos KBAC, Deus ZLC.. Practice of physical activity on the part of adolescents attending public schools: a descriptive study. Online braz j nurs [Internet]. $2013 \mathrm{Apr}$ [cited year mouth day]; 12 (1): 209-17. Available from: http://www.objnursing.uff.br/index.php/nursing/article/view/3632 
proportion of the sample that practiced physical activity was engaged in that program,

which shows the importance of its implementation in all schools.

\section{REFERENCES}

1. Ferreira JS, Aydos RD. Prevalência de hipertensão arterial em crianças e adolescentes obesos. Ciênc saúde coletiva. 2010; 15(1): 97-104.

2. Yokota RTC, Iser MPM, Andrade RLM, Santos J, Meiners MMMA, Assis DM, Bernal RTI. Vigilancia de fatores de risco e proteção para doenças e agravos não transmissíveis em município de pequeno porte, Brasil, 2010. Epidemiol Serv Saúde. 2012; 21(1): 55-68.

3. Ministério da Saúde (BR). Portal da saúde [homepage na internet]. Reportagens Especiais. $13 \%$ dos adultos são obesos [Cited 2010 out 20]. Available from: http://portal.saude.gov.br/portal/aplicacoes/reportagensEspeciais/default.cfm?pg=ds pDetalhes\&id area $=124 \&$ CO NOTICIA $=10078$.

4. Azevedo MR, Araujo CL, Silva MC, Hallal PC. Tracking of physical activity from adolescence to adulthood: a population-based study. Rev Saúde Pública. 2007; 41(1): 69-75.

5. Malta DC, Sardinha LMV, Mendes I, Barreto SM, Giatti L, Castro IR, Moura L. Prevalência de fatores de risco e proteção de doenças crônicas não transmissíveis em adolescentes: resultados da Pesquisa Nacional de Saúde do Escolar (PeNSE). 2009; Ciênc saúde coletiva. 2010; 15 (Suppl 2): 3009-19.

6. Souza LJ, Gicovante Neto C, Chalita FEB, Reis AFF, Bastos DA, Souto Filho JTD, Souza TF, Côrtes VA. Prevalência de obesidade e fatores de risco cardiovasculares em Campos Rio de janeiro. Arq Bras Endocrinol Metab. 2003; 47(6): 669-76.

7. Freitas RWJF, Silva ARV, Araújo MFM, Marinho NBP, Damasceno MMC, Oliveira MR. Prática de atividade física por adolescentes de Fortaleza, CE, Brasil. Rev Bras Enferm. 2010; 63(3): 410-5.

8. Ceschini FL. Análise descritiva do nível de atividade física em adolescentes de uma escola pública do distrito da Vila Nova Cachoeirinha em São Paulo - SP. Dissertação [Mestrado em Saúde Pública]. São Paulo: Faculdade de Saúde Pública da USP; 2007.

9. Souza CO, Silva RCR, Assis AMO, Fiaccone RL, Pinto EJ, Moraes LTLP. Associação entre inatividade física e excesso de peso em adolescentes de Salvador, Bahia Brasil. Rev Bras Epidemiol. 2010; 13(3): 468 - 75.

10. Damasceno MMC, Silva ARV, Vasconcelos HCA, Araújo MFM, Almeida PC, Freitas RWJF. Overweight and obesity in public schools adolescents from Fortaleza: na exploratoty stydy. Online Braz J Nurs [serial in the internet]. 2007 [cited 2009 mar 18]; 6(3). Available from: http://www.objnursing.uff.br/index.php/nursing/article/view/966.

11. Romero A. Relação da atividade física com o estado nutricional e marcadores bioquímicos em adolescentes de escolas públicas de Piracicaba. São Paulo. [tese de doutorado]. São Paulo: Faculdade de Saúde Pública da USP, 2012.

12. Teixeira e Seabra AF, Maia JA, Mendonca DM, Thomis M, Caspersen CJ, Fulton JE. Age and sex differences in physical activity of Portuguese adolescents. Med Sci Sports Exerc 2008; 40(1):65-70.

13. Troiano RP, Berrigan D, Dodd KW, Masse LC, Tilert T, McDowell M. Physical activity in the United States measured by accelerometer. Med Sci Sports Exerc 2008; 40(1):181-8.

14. Santos MS, Hino AAF, Reis RS, Rodriguez-Añez CR. Prevalência de barreiras para a prática de atividade física em adolescentes. Rev Bras Epidemiol 2010; 13(1): 94104.

15. Ceschini F, Figueira JA. Barreiras e determinantes para a prática de atividade física em adolescentes. $\mathrm{R}$ bras $\mathrm{Ci}$ e Mov 2007;15(1):29-36. 
16. Reichert FF, Barros AJ, Domingues MR, Hallal PC. The role of perceived personal barriers to engagement in leisure-time physical activity. Am J Public Health 2007; 97(3):515-9.

17. Gobbi S, Caritá LP, Hirayama MS, Quadros-Junior ACd, Santos RF, Gobbi LTB. Comportamento e Barreiras: Atividade Física em Idosos Institucionalizados. Psicologia: Teoria e Pesquisa 2008;24(4):451-458.

18. Tenório MCM, Barros MVG, Tassitano RM, Bezerra J, Tenório JM, Hallal PC. Atividade física e comportamento sedentário em adolescentes estudantes do ensino médio. Rev Bras Epidemiol 2010; 13(1): 105-17.

19. Rivera IR, Silva MAM, Silva RDTA, Oliveira BAV, Carvalho ACC. Sedentarismo e composição corporal em jovens. Arq Bras Cardiol 2010; 95(2): 159-165.

20. Brito AKA, Silva Júnior FL, Coelho LS, França NM. Nível de atividade física, índice de massa corporal e percentual de gordura em escolares. Rev Bras Ativ Fis e Saúde $2012 ; 17(3): 212-216$.

Received: $30 / 09 / 2011$

Approved: 20/09/2012 